\title{
THE ADVANTAGES OF NUMBERS OF ENGLISH TEXT BOOKS IN STUDENT'S READING COMPREHENSION AT THE THIRD SEMESTER OF TBI IAIN MADURA
}

\author{
Tutik Wijayanti \\ English Teaching and Learning Program, Tarbiyah Faculty, IAIN Madura \\ tutikwijayanti84@gmail.com \\ Hasan Basri \\ English Teaching and Learning Program, Tarbiyah Faculty, IAIN Madura \\ basrie_hasan@yahoo.com
}

\begin{abstract}
The number of English textbooks facilitates the students in their reading comprehension process because it will help them easier in comprehending the text and increasing the student's knowledge. This research investigates about what are the advantages of numbers of English textbooks in student's reading comprehension at the third semester of TBI IAIN Madura (Formerly STAIN Pamekasan) and how do the numbers of English textbooks help in student's reading comprehension. 10 students are observed. The study was conducted using narrative qualitative research. The data are gotten from observation, interview, and documentation. The result of this research shows that there were four advantages of numbers of English textbooks in student's reading comprehension, they are as a source of knowledge, as the references, as a training to have better thinking, and as pleasure. And how the numbers of English textbooks help in student's reading comprehension, most of the students realize that by reading several books, it helps them easier in comprehending the text, reaching higher levels of thought, add up new vocabularies, understanding reading text easily.
\end{abstract}

Keywords: Reading Comprehension; English Text Books

First Received:

September $4^{\text {th }}, 2019$
Final Proof Received:

September 09th, 2019

\section{INTRODUCTION}

Reading is one of the important ways to improve one of language skill in English because students need to comprehend and deal with all reading aspects and difficulties. Reading is also a good way to find out about new ideas, facts, and experiences. Reading has a positive effect on student's vocabulary knowledge, on their spelling, and on their writing, so the students simply get knowledge base on the text that they read but also it will improve the student's skill in reading.

In general, the essence of reading is made up recognizing or identifying, interpreting, and responding the components of written messages. It means that individuals, in this case, the students have to understand and interpret the meaning of words to achieve their own goals or interests. But the students will lose their concentration and interest when they found any difficulties and less comprehending to the text that they read, of course in learning reading the students should select and choose the interested text to improve their reading comprehension. 
Reading comprehension is the result of thinking which is triggered by visual symbol. It means that in reading need some aspect process of thinking, such as memorize, comprehension, analyze, and the final process is applied what they read. The sum total the meanings of individual words and phrases do not add up to the meaning of a given piece of writing. Reading English text is different than reading Indonesian text, English is as foreign language or second language for us, the readers are easier to comprehend the Indonesian texts because it is our language. In the English text should know the meaning of words, readers need English dictionary but it is not enough to comprehend the English text, readers should know any kinds of media that can help them to comprehend the texts easily.

Numbers of English text books is one of the ways to help in the student's reading comprehension and to find specific information in a text while ignoring it is broader meaning and misinterpreting. It is possible for students to learn base on their interesting and their capability from number of books that they want to read (Sadiman, 2011: 13-15). Number of English text books will help the students to get knowledge whether in or out the class. It means that in classroom activities the students have got knowledge from their teachers as the instructor or from their handbook, in out of class the students can get knowledge from some resources such as English text books, which can increase their knowledge. Of course, those not only for increasing their knowledge but also improving their skill. In Indonesia, on 17 May always be celebrated as "The Book's day" (Setiawan, 2008: 181). It was one of proof the importance of books as media to transfer knowledge for the students, and those celebration remains us to have good reading habit. Thus, in students reading comprehension, the students have to know any kinds of books to which support them in comprehending the text easily, interpreting, and responding the components of written text to measure and improve their reading ability.

The students can use a variety of resources and media in learning process. Numbers of English text books give strong motivation in learning process, the students do not only get knowledge from the teachers but also any kinds of book will be knowledge resources. ${ }^{4}$ The students will select the interesting text to grow up their self motivation in reading, because in reading the students need hard work and sometimes will make them frustrated and get bored, so that they will lose their attention in reading. Thus, selecting the kinds of text base on their interesting it would attract them to read. Absolutely, the students have to know what kind of book that can support their English skill beside of their interesting.

The researcher researches this study because she wants to know more about the roles of number of books in student's reading comprehension, as we knew the importance of reading books in our life well for getting information or increasing knowledge by reading a book and from those books, the readers have motivation to read. Here the researcher wants to know the roles of number of books which help the students in their reading comprehension, the researcher tries to get the data on the field about the roles of 
number of books on student's reading comprehension. Thus, the present study is intended to explore the roles of number of books in student's reading comprehension and it is expected that this research will contribute to reading teaching and number of books as the media to improve student's reading comprehension.

\section{LITERATURE REVIEW}

\section{The Nature of Reading}

Reading is made up recognizing or identfying, interpreting, and responding the components of written messages. Diane Henry Leipzig explained that reading is a multifaceted process involving word recognition, comprehension, fluency, and motivation. Learn how readers integrate these facets to make meaning from print. Reading is making meaning from print (Leipzig, 2001).

\section{Reading Comprehension}

Definition of comprehension is a "creative, multifaceted process" dependent upon four language skills: phonology, syntax, semantics, and pragmatics ('Reading comprehension', 2014). There are specific traits that determine how successful an individual will comprehend text, including prior knowledge about the subject, well developed language, and the ability to make inferences. Reading comprehension is the process of making meaning from text. The goal, therefore, is to gain an overall understanding of what is described in the text rather than to obtain meaning from isolated words or sentences.

\section{Effective Techniques for Reading}

a. Before reading

It means that the readers should know what have to be done before they read the text, this technique helps them to have good understanding and for a training effectively. Before reading a book, the readers should know as follow (Djuharie, 2008: 11):

1. Preview the reading headings to get a "big picture" of the outline of reading. Look at the pictures and figures. Check out the bold and italicized words.

2. Preview any questions that the chapter may offer so that you can actively seek the answers to those questions.

3. Turn text headings into questions so you can actively answers to those questions.

4. Plan for a high energy time of the day to read. Consider breaking up a long reading assignment into multiple, shorter reading sessions.

5. Be sure you have your materials for materials.

b. During Reading

While reading, the readers should not read the text directly but it's better for them if they want to follow this steps:

1. As you are reading, seek out the answers to the questions that the reading. 
2. Monitor your concentration and comprehension. After each paragraph, ask yourself, "what was the main point of that paragraph?" Summarized what you have learned.

3. Mark your text. Highlight the main idea of the paragraph or write down the main idea of a paragraph in your notes. Do not mark or highlight in your text until you have completed reading.

4. Look up the definition to words that you do not understand to help building your vocabulary and facilitate understanding of the topic.

c. After Reading

After reading a text, the readers should not close the text that you have read but you need to save what have you read in your mind, capture the information you need, and make notes. The readers can follow the steps:

1. Take reading notes from the highlighted material from the text.

2. Answer the question that the reading may have provided or that you developed.

3. Integrated your reading notes.

4. Discuss reading with classmates on a regular basis. Take turn explaining to each other sections of the reading. If you find the difficulty, you can share it to your guide or lecturer.

\section{Reading Strategies}

a. Skimming

Reading selectively to get a general idea of what an article is about, in this case, the readers have to select about the general idea in a text that they read to get the information as quick as possible relates to the text. The readers should look for the main idea of the text, and the most important ideas of the text. The readers use skimming to find out the main idea on the text that they read.

b. Scanning

Reading the text quickly by speed up the eyes to get the important message of the text, it is called as the natural skill. The readers try to read a text as quick as possible by speed up the eyes to get the important message on the text that they read, it helps the readers to get the information that they need on the text quickly and it relates to the reader's habit on reading several books/information because a reader will get the information on the text quickly by scanning if he has good habit on reading. The readers use scanning to find out the specific information from the text that they read.

c. Extensive reading

Reading a much of the text, and usually it is for pleasure. And it relates to comprehend the global meaning. Here the readers read the text to get the information of the text and comprehending the global meaning of the text.

d. Intensive reading

Read a short text to explore the specific information, it relates to accuracy to know as detail of information. In this case, the readers read a simple/short text but the purpose 
is to explore the meaning and specific information on the text that they read, the readers will find the information on the text in detail.

\section{The Nature of Book}

Book is number of printed sheets of paper fastened together in a cover (Oxford Learner's Pocket Dictionary, 2008). A book is a set of written, printed, illustrated, or blank sheets, made of ink, paper, parchment, or other materials, usually fastened together to hinge at one side. A single sheet within a book is called a leaf, and each side of a leaf is called a page.

\section{A Few Tips to Choose a Book to Read}

There are three tips for the readers before chosing the book they want to read (Singh, 2012).

a. Consider the interests

What are the students interested in? if the students like learning about famous people and their stories, they shall check out the biography of their favorite historical figure (Singh, 2012). The students will select anything base on their interesting firstly, because it will stimulate them to read. Each of students has their own interesting such as a book with colorful in the cover, a book with a piece of pictures, etc.

b. Ask your friends

If the students like to share a lot of interests with their friends, chances are they will enjoy some books, as well. And they will share much of books that they like to read. The students would like any friends to discuss on their interesting, it will grow up their interesting to read a book, and sometimes they did not want to leave a chance to read book if they knew that their friends were read that book.

c. Join a book club

A great way to introduce the new titles and authors, the students are also a great way to make good friends that they may share same interests with. Here is how book club works : all members of the group will read the same book at the same time. Every so-often (differentbook clubs have different lengths of time between meetings), everyone will meet up, often over coffee or dinner to discuss the book.

Absolutely, this kinds of effective way to grow up a good reading habit (Singh, 2012). Here, the students not only can share what they read but also analyze about it because they have a long time to read a book which is chose and can compare with the groups about the points that they have got.

\section{The Importance of Books in Life}

a. Reading books as pleasure

The joy of reading books can't be described in words. It's something that you understand only by real experience. Reading books as someone's pleasure, it means that 
by reading a book it will make you interest because you could spend much of your time on your activities but when you feel bored you can take and reading books to make you enjoy and refresh your mind (Djuharie, 2008: 12).

b. Reading books as improving yourself

What starts with reading story books, when you are a kid, turns into reading books for improving yourself as you grow older. From story books to technical and management books, and then from self improvement books to spiritual books and beyond, the journey is fantastic and you learn something with each passing day ('Buku', 2014).

c. Reading books are not as reading article

Thanks to technology that it can easily find good articles to read on the internet. A great article can inspire and motivate you as much as a great book. It's not how much you read, but what you read which is more important.The only reason that reading books over short articles is because when you read a book you spend several hours with it, whereas you only spend a few minutes reading an article.

d. Reading books to make a better thinking

You understand your thoughts and emotions more clearly. It makes you realize who you really are and makes your life more meaningful. It makes you a better thinker and a better man. Also, reading good books is not enough. The way you read it is more important.

e. Number of books as the source of knowledge

It is possible for students to learn base on their interesting and their capability from number of books that they want to read (Sadiman, 2011: 13-16). It indicates that a teacher is not a central media to transfer knowledge to their student, thus, number of books will help the students to get knowledge whether in or out the class.

f. Number of books as a vital role in the language learning process

Bilingual books play a vital role in the language learning process of children. Whether you are trying to teach your home language or the language at school, books can be your best companion and tool in assisting you in the process (What is the role of books in Language Learning, 2014).

g. The book is an object

Indeed, the book, ideal support for initiating and learning to read, is above all we must not forget it a physical object that the child must domesticate. By manipulating it, chewing on it, sucking it, turning it around in every sense, the child slowly takes possession of his book.

\section{RESEARCH METHOD}

Conducting a research the researcher needs approach in order to make the process of the research easier. There are two kinds of approaches in educational research; they are quantitative and qualitative approach. Qualitative research is an inquiry approach useful for exploring and understanding central phenomenon (Creswell, 2012,: 626). 


\section{Research Design}

The researcher in this research uses qualitative research and kind of the research is descriptive research. Because, this research explains and explore about the phenomenon which in this case the phenomenon is the advantages of numbers of English text books in student's reading comprehension. So, the data that used in this research are in the form of words or pictures rather than numbers and statistics.

\section{Data Sources}

The source of data will be gotten from the students at the third semester of TBI IAIN Madura. It helps the researcher to get information while doing the research. And the source of data in this research is the student's reading comprehension by using numbers of English text books in which the students as the subject who decide to increase their reading comprehension by using numbers of English text books. And the data of student's reading comprehension by reading number of books is in form of descriptive data. The researcher collects the data from interview. The data is question that will be delivered by researcher orally to the subject of research which refers to research focus. The researcher will interview the students to get the information about their reading comprehension by reading numbers of English text books. And the object is reading comprehension by reading numbers of English text books.

\section{Data Collection Procedure}

Collecting data means identifying and selecting individuals for a study, obtaining their permission to study them, and gathering information by asking people question or observing their behaviors (Creswell, 2012: 9).

\section{a. Observation}

The researcher will observe the activities and the condition of the object of the research to get the information and data, then, she will record the result of the observation. There are two kinds of observation, they are; participant observer and nonparticipant observer. Participant observer is an observational role adopted by researchers when they take part in activities in the setting they observe. Whereas, nonparticipant observer is an observer who visits a site and records notes without becoming involved in the activities of the participants (Creswell, 2012: 214-215). The data of observation will be the advantages of numbers of English text books in student's reading comprehension and how the numbers of English text books help in the student's reading comprehension.

\section{b. Interview}

Interviews are used to gather data from people about opinions, beliefs, and feelings about situations in their own words. They are used to help understand the experiences people have and the meaning they make of them rather than to test hypothesis. Interviews may provide information that cannot be obtained through observation, or they can be used to verify observations (Ary, Jacobs, Razavieh, \& Ary, 2010: 438). 
The researcher will do the interview in the library to students at The Third Semester of TBI (Tadris Bahasa Inggris), whereas the students are the object in doing the activities that is reading and numbers of English text books as one of their media in reading comprehension. In this case, the researcher uses unstructured interview because the researcher will ask some questions without prepare it first to get the information during the interview, in order the interview will happen naturally, the interviewees will not think that they are interviewed.

\section{c. Documentation}

After the interview used on collecting the data, then for the next technique is documentation, it is to prove the original of the data that researcher got. Document is one of the important part in the research because it is very need by the researcher to collect the data that have gotten while the research process, and to support the data such as taking the pictures deal with the students activities while reading and numbers of English text books as their media in reading comprehension. Thus, the documentations help the researcher to prove her research.

\section{RESULTS AND DISCUSSION}

\section{The Advantages of Numbers of English text Books in Student's Reading Comprehension}

From the data that is gotten from research field, it is clear that the most students know the advantages of numbers of English text books on their reading comprehension process, it is followed by some reason of them on using the numbers of English text books in their reading comprehension process of the text that they read, they are the English text books as the source of knowledge, the English text books as the references, the English text books as a training to have a better thinking, and the last is the English text books as pleasure.

a. The Number of Books as the Source of Knowledge

One of TBI students of A class said that the advantages of numbers of English text books is as the source of knowledge, the name is Lukman Hakim stated that:

"the number of English text books which I have read should add my intellect because the numbers of English text books will help me know anything that I don't know before" (Hakim, 2014).

The students admitted that when they read the numbers of English text books, they will be more intellect because the numbers of English text books that they read will increase the student's knowledge and give them some experiences. In classroom activities the students have got knowledge from their teachers as the instructor or from their handbook, in out of class the students can get knowledge from some resources such as books, which can increase their knowledge. 
b. The Numbers of English Text Books as the References

From the advantages of English text books that is the English text books as references, the students had strong motivation to read the English text books so that they pay much attention on reading those book if they need the English text books as references. Beside the activity above, the advantages of numbers of English text books that they read will improve their reading comprehension process. Most of TBI students said that the numbers of English text books as the references, one of TBI students of A class named Inni Marroh Qonitatillah stated that:

“...... honestly, I dislike to read a book even though I knew that book is very important for me, I think it's because I would like to listen than to read, but I have still used the number of books as the references because the number of books are important for me as reference when I have gotten some duties from my lecturer. Of course, I have read those books well to support an idea or to understand what the topic is about, and from that habit little by little I can comprehend the text easily. It's not like when I never want to read books before" (Qonitatillah, 2014).

It is indicating that the students know the important of reading books in life, even though they dislike reading books but after they read several books they feel that books give them more experiences, for example the students read books as references because they need it to fulfill they homework, from this example the students look like did not know the important of books except as references for them, but they will feel more intelligent when they have read it because by reading the English text books not only for collecting the theories to support an idea but also give more knowledge and experiences to them.

\section{c. The Numbers of English Text Books as a Training to have a Better Thinking}

In this case the advantages of numbers of English text books show that the students need to read several English text books because it is not only for reading but also as training for a better thinking, Which the numbers of English text books can make a training to the students to give a new idea or a different opinion of the text that they read, think upon it deeply, don't accept or reject it blindly, try to reason with it and understand the writer's point of view.

One of TBI students of B class said that the advantages of numbers of English text books is as a training to have a better thinking, the name is Suyanto stated that:

"...... of course, the more I read the English text books, it will make better the way i think but it will be happened if I read the English text books for training my thinking, for example from the numbers of English text books that I have read, I have found any kind of the text whether it's easy or difficult to understand, so of course when I find the difficulties in comprehending that text I will try to find the problems solving well it is by looking for the dictionary, try to translate it word by word, or discussing with my friends" (Suyanto, 2014).

The result indicated that majority of the students read the books not onl to get information but they use the books for training their thinking, it means that the way they 
read those books are more important besides getting information because when they read the books, they will find some ideas of the author on that books and as a reader has to have many reasons to accept or reject about writer's point of view. This way almost used to make the readers have better thinking.

d. Reading the Numbers of English text Books as Pleasure

Lukman Hakim stated that:

"the number of books that I have ever read, most of them based on my favorite books, because I like to read the text like recount, narrative, and about learning strategies. I never read those books are finished in one time, because I have much of activities, so if I haven't an activity I will continue to read those books" (Hakim, 2014).

\section{The Numbers of English Text Books Help in Student's Reading Comprehension}

Reading is one of important skill in developing our ability in English. By reading, the students can get information and knowledge. Reading will make the students easy in finishing examination because as we know that the question in examination related with the text and need reading skill to solve it and to comprehend it well.

In reading comprehension process, the researcher found how the numbers of English text books help in the student's reading comprehension. They are as follow:

a. Easier to Comprehend the Text

The students are difficult in understanding the meaning of the words, phrases, sentences, moreover passage so that they are lazy to read the books. However, they have obligation to receive and understand the materials related with whole subject in their school, especially reading materials. The numbers of English text books help in student's reading comprehension because the students will experience in comprehending the text. It means that the students for the first time will find any kind of difficulties that they have found on the text that they read but if the students always find those difficulties it will help them to comprehend the other's text easily because they have experienced it.

One of TBI students of $\mathrm{C}$ class said that the numbers of English text books easier in comprehending the text, the name is Musarrofah stated that:

"I always find the difficulties on comprehending the text that I read, because they are a new text, new vocabularies, and new context for me, but from the number of books that I have read, make me easy in comprehending another's text because I have experienced it (Musarrofah, 2014)."

It is also supported by Lukman Hakim as TBI student of A class stated that:

“..... I think when I have habit in reading books, it will make me easier to comprehend the text and decrease the difficulties that I found in reading the text" (Hakim, 2014).

The result indicated that the majority of the students can decrease the difficulties from the text that they read when they have habit or always reading books, because the experiences when they read the books will help them to face some difficulties that they will find in another text while reading the text. 
b. Reaching Higher Levels of Thought

One of TBI students of A class said that the numbers of English text books help in reaching higher level of thought, the name is Nur Hidayati stated that:

"by reading several books can reach higher level of thought because when I read book, it needs level of thinking that is very need for comprehending the text easily. It doesn't need reading strategies only, but also experiences and focusing to the context on the text" (Hidayati, 2014).

It is also supported by Inni Marroh Qonitatillah as TBI student of A class stated that:

“......actually in reading books, beside I need the information on what I read and I want to be more criticize to the text that I read because sometime the text that I read, it is not logic and I need to criticize it as well as I know and I realize that I need to have good habit on reading because I always feel difficult in comprehending the text" (Qonitatillah, 2014).

It indicates that the students know that by reading books can help them in reaching higher level of thought after they read several books and they realize the way they read is the important thing to be donewhile reading books because in comprehending process of the text, it need a best way to catch the meaning of writers' point of view.

c. Add up New Vocabularies

One of TBI students of $C$ class said that the numbers of English text books can add up the student's vocabularies. Tohiroh stated that:

"I agree to someone's statement that by much of vocabularies will help skill in English, well in speaking skill, writing skill and of course in reading skill. So that, the number of books that I have ever read, they give me much of new vocabularies that can help me to communicate and comprehend the other's text easily and of course I needn't waste much time to look for vocabularies on the dictionary because I have still remembered it on the other text that I have ever read (Tohiroh, 2014)."

\section{d. Little by Little}

One of TBI students of A class said that the numbers of English text books helpin student's reading comprehension little by little. Nur Hidayati stated that:

"as long as my experienced in reading several books, I never finish for reading a book in one time even though the book I read is interesting, I always read it little by little in my spare time because I need to comprehend it and not for reading only and I think it's not enough for me because I still need much of books to read specially to improve my reading skill (Hidayati, 2014)."

It is indicating that the students know about their condition while reading books, so that they read books little by little for finishing it because they preferred reading books to spend their spare time and for enjoying.

\section{CONCLUSION}

The advantages of numbers of English text books in student's reading comprehension process, they are the numbers of English text books as the source of 
knowledge, the numbers of English text books as the references, the numbers of English text books as a training to have a better thinking, and the numbers of English text books as pleasure. It also found that most of students agreed that they need to read books because the numbers of English text books as the source of knowledge that can make them more intellect and increasing knowledge. The majority of the students agreed that the numbers of English text books as the references for them, beside, it can help the students in their reading comprehension process. The students also realized that by reading the numbers of English text books, it can make the students have a better thinking because the way they read while reading the text it is more important. The students mostly did not spend their time to read the English text books when they have business or other activities, and the students preferred reading books that is the interesting books for them. The numbers of English text books help in student's reading comprehension they are the numbers of English text books help in easier to comprehend the text, the numbers of English text books help in reaching higher level of thought, the numbers of English text books help in adding up new vocabularies, and the numbers of English text books help in student's reading comprehension process little by little. Reading also helps the students to comprehend another text easily because they have experienced it. It also helps them in reaching higher level of thought, and adding their vocabularies as well.

\section{REFERENCES}

Ary, D., Jacobs, L. C., Razavieh, A., \& Ary, D. (2010). Introduction to research in education (8th ed). Belmont, CA: Wadsworth.

Buku. (2014). In Wikipedia bahasa Indonesia, ensiklopedia bebas. Retrieved from https://id.wikipedia.org/w/index.php?title=Buku\&oldid=15440498

Creswell, J. W. (2012). Education Research. Boston: Pearson Education.

Djuharie, O. S. (2008). Intensive Reading Bottom up Reading. Bandung: CV. Yrama Widya.

Leipzig, D. H. (2001, January). What Is Reading? | Adolescent Literacy Topics A-Z | AdLit.org. Retrieved 29 August 2014, from http://www.adlit.org/article/352/

Oxford Learner's Pocket Dictionary (4th ed.). (2008). Oxford: Oxford University Press.

Reading comprehension. (2014). In Wikipedia. Retrieved from https://en.wikipedia.org/w/index.php?title=Reading_comprehension\&oldid=910 418844

Sadiman, A. (2011). Media Pendidikan. Jakarta: PT. Raja Grafindo Persada.

Setiawan, B. (2008). Agenda Pendidikan Nasional. Yogyakarta: Ar-Ruzz Media.

Singh, R. (n.d.). The Importance of Reading Books. Retrieved 14 September 2014, from http://www.singhrahul.com/2012/08/the-importance-of-reading-books.html

What is the role of books in Language Learning. (2014). Retrieved from www.thelanguagebear.com/what-is-the-role-of books-in language-learning

http://en.wikipedia.free ensyclopedia /reading_ comprehension. Accessed on 28 March 2014.

http://reading resources and help/developing reading-skill. Accessed on 11 May 2014. 
Id.wikipedia.org/wiki/buku, accessed on 10 September 2014.

www.thelanguagebear.com/what-is the-role-of books- in languiage-learning, Accessed on 12 September 2014.

\section{Interview Sources:}

Hakim, L. (2014, November 23). The student at the third semester [Direct Interview].

Hidayati. (2014, November 25). The student at the third semester [Direct Interview].

Musarrofah. (2014, November 25). The student at the third semester [Direct Interview].

Qonitatillah, I. M. (2014, November 24). The student at the third semester [Direct Interview].

Suyanto. (2014, November 24). The student at the third semester [Direct Interview].

Tohiroh. (2014, November 26). The student at the third semester [Direct Interview]. 
Tutik Wijayanti, and Hasan Basri, The Advantages of Numbers of English Text ... 